\title{
MODERATE ISLAM AND ITS RELEVANCE IN THE POST 9/11 AMERICA AS IMPLIED IN IMAM FEISAL ABDUL RAUF'S MOVING THE MOUNTAIN
}

\author{
Rifka Pratama \\ Universitas Diponegoro, Semarang \\ pratama.rifka@gmail.com
}

\begin{abstract}
American Muslim is one of some existing religious minorities in America. Despite of minority, this religious group has been long, some believed it has been even since the Columbus exploration, living in the country. As time goes, the American Muslims are able to blend with American Society. These Muslim individuals are found in many fields of life of American, such as social, economic, education, and even politics in America. This condition is anyway worth appreciating as the struggle of American Muslims for their existence is not something simple and easy. Apart from the reality, the deadly attacks of 9/11, to some extent, has put American Muslims to be objects of suspicions. Soon after the tragedy, Muslims in many occasions are prejudiced as harsh, and of course, terrorists. These suspicions and prejudice have been, in fact, long found in the middle of American society pre-9/11 attacks. However, the tragedy aggravates the status quo of the American Muslims and it soon creates the worst point of so-called Islamophobia. In response to this phenomenon, many American Muslims start to deliver counters in various ways and media. Among the American Muslim figures, Imam Feisal Abdul Rauf, an American Muslim activist and leader, actively brushes off the bad images of Islam, especially regarding the 9/11 tragedy. Through his book entitled "Moving the Mountain: beyond Ground Zero to a New Vision of Islam in America", Rauf explains his views on Islam. This book also implies counters to the so-called phenomena of Islamophobia. On the other hand, Moderate Islam contains the same spirits with Rauf's Moving the Mountain. It offers the spirit of moderation in understanding and practicing Islam. Both the ideas in turn are able to counter Islamophobia in America, especially in post 9/11 America.
\end{abstract}

Keyword: American Muslims, Imam Feisal Abdul Rauf, Moving the Mountain, Islamophobia, Moderate Islam

\section{Introduction}

The 9/11 tragedy in America has shocked people all over the world. It soon makes Islam a controversial topic especially among the public of America. This deadly attacks have significantly affected the views of some Americans on Islam and Muslim. Out of the impacts, as the suspect behind the tragedy Al-Qaeda is considered responsible for making Islam a center of attention among the public of America.
Since the organization commanded by Osama bin Laden is labeled as Islamic Militant, it becomes inevitable for the likelihood of distortion in differentiating Islam and terrorism. Far before the 9/11 this phenomenon has been actually happened. Homerin (2006) suggested, "for many Americans the word Muslim invokes a host images: a veiled woman, a robed Bedouin on camelback, an angry black man, and, especially today, an Arab terrorist" (p. 105). 
Especially after the 9/11, some people are trapped to generalize the Islamic Militant groups with Islam which is practiced by the mainstream. Consequently, this second largest religion is often viewed as one which promotes hatred and terrorism. In fact, Al-Qaeda, which is also a part of the militant groups, is only a small faction in Islam. A survey of people's views on AlQaeda done by Pew Research Global Attitudes Project in 2014 shows that the militant group gets negative marks in all 14 countries surveyed (para. 15). It is surprising as the countries are mostly populated by Muslims. Strong majorities in most countries have unfavorable opinions of the group ${ }^{1}$.

Bad images of Islam that exist in the public of America, in turn, potentially create prejudice and hate crimes against American Muslims. Anderson (2002) found that "following September 11, 2001, the Federal Bureau of Investigation (FBI) reported a 1,700 percent increase of hate crimes against Muslim Americans between 2000 to 2001" (as cited in Khan and Euckland, 2012, para. 1). As reported by CAIR (Council on American-Islamic Relations), there were also 1717 reports of harassment, violence, and other discriminatory acts to Muslims in the first six months after the 9/11 attack (para. 1).

Being a minority group in the midst of bad images and prejudice, Muslims in America find it difficult to live a normal life especially at the days following the $9 / 11$.

1

More

info

visit:http://www.pewglobal.org/2014/07/01/co ncerns-about-islamic-extremism-on-the-risein-middle-east/
On this matter, Eck (2002) affirmed, "although Muslim groups condemned terrorist violence, there was an unprecedented wave of attacks on Muslims and Muslim communities" (p. x). She further narrated violences against Muslims community in the US in the aftermath of $9 / 11$. The following is her narrative:

"In the days following the attack, a furious man smashed his car through the plate-glass door of the mosque in Cleveland. A crowd approached the Bridgeview mosque in Chicago shouting antiArab slogans. As Muslims gathered at their mosque in Sterling, Virginia, to take a chartered bus to a blood drive, they found a message inscribed on the building in big black letters: "Die Pigs" and "Muslims Burn Forever!" In Alexandria, Virginia, someone hurled bricks wrapped with hate messages through the windows of an Islamic bookstore, shattering the glass. A firebomb landed in the mosque in Denton, Texas, on the outskirts of Dallas, and rifle fire pierced the stainedglass dome of the mosque in Perrysburg, a suburb of Toledo, Ohio. The rash of scattershot incidents across the country also included Hindu temples attacked in Medinah, Illinois, and in Matawan, New Jersey; a Gujarati owned convenience store firebombed in Somerset, Massachusetts; and an Iraqi pizzeria burned down in Plymouth, home of the Pilgrims" (p. x).

The 9/11 attacks has led many further incidents in the American life. In line with this, Peek (2001) added, "the attacks have 
unleashed an almost unimaginable torrent of pain and destruction" (p. 1).

According to Peek (2001), "over the two decades prior to the $9 / 11$ terrorist attacks, several scholars of Islam had began to write with an increasing degree of urgency about the rise of anti-Muslim hostility in the United States" (p. 36). Nowadays, the phenomenon evolves into the worst form. People called this Islamophobia. Center for Race and Gender University of California (2001) defined it as "unfounded hostility towards Muslims, and fear or dislike against all or most Muslims" (para. $1)^{2}$. The term was first introduced as a concept in a 1991 Runnymede Trust Report. The phenomenon has actually existed in premise before the terrorist attacks of September 11, 2001, but it increased in frequency and notoriety during the past decade ("Islamophobia:Understanding AntiMuslim Sentiment in the West", 2008, para. 4) ${ }^{3}$. Islamophobia designates the irrational fear of Islam that drives people to make blanket judgments accusing all Muslims (over a billion people) of harboring the same murderous fantasies that Muslim extremists express and act upon ${ }^{4}$.

\section{Defining "Islamophobia",} http://crg.berkeley.edu/content/islamophob ia/defining-islamophobia

\section{Islamophobia: Understanding Anti-} Muslim Sentiment in the West. http://www.gallup.com/poll/157082/islamo phobia-understanding-anti-muslimsentiment-west.aspx

\section{Islamophobia and Criticism of Islam.} http://www.theaugeanstables.com/reflectio ns-from-second-draft/islamophobia-and-
In 2011, an interesting article about antiMuslim sentiments in America written by Engy Abdelkader was published online by the Huffington Post. The article is entitled 5 Myths about American Muslims 10 Years After 9/11. Within the writing Abdelkader mentions five common prejudices on Muslims in America. Briefly, those five prejudices are written below ${ }^{5}$ :

1. American Muslims do not cooperate with law enforcement officials.

2. Mosques are hotbeds of extremism and terrorism in the American Muslim community.

3. Sharia is threatening to infiltrate the American legal system.

4. Muslim leaders don't condemn acts of terrorism committed in the name of Islam.

5. Every practicing Muslim engages in taqiyyah, which is religiously mandated lying.

If those five prejudices are what American believed about Muslim so far, it would be hard for Muslims in America to practice and to publicly show their religious identity. Without any counters, those kind of prejudice would potentially turn into Islamophobia. The fact also shows that Islamophobia does not only exist among common people in America. Yet, some American intellectuals and public figures also embrace and promote this unfounded hostility. Pastor Terry Jones, for example, once shocked Muslims worldwide. With

criticism-of-islam/

5 For a complete article see: 5 Myths About American Muslims 10 Years After 9/11. Posted: 09/08/2011 6:33 pm EDT. http://www.huffingtonpost.com/engyabdelkader/myths-about-american-muslimsafter-911_b_946003.html 
the nine-year anniversary of $9 / 11$ on the horizon, he concocted 'the International Burn a Koran Day', to honor 9/11 victims no less ${ }^{6}$. For some Muslims such kind of prejudice and violence would be so offensive. Yet, today Islamophobia is a reality to face.

The emergence of Islamophobia in America has triggered many responses from both Muslims and non-Muslims. Peek (2001) noticed, "in the aftermath of 9/11 countless scholarly articles, books, edited volumes, and impressive pieces of investigative journalism have dissected and analyzed the events leading up to and the consequences of the terrible calamities that will forever mark that moment in history" (p. 1). These responses, whether it is a counter or a justification, are delivered to the public. The issues on Islamophobia soon become trending topic among American.

Within Muslim communities there is much disapproval toward any form of terrorism on behalf of Islam. Recently, across 11 Muslim publics surveyed by the Pew Research Center, a median of $67 \%$ say they are somewhat or very concerned about Islamic extremism. In five countries - Pakistan, Jordan, Tunisia, Turkey and Indonesia - Muslim worries about extremism have increased in the past year?

6 The War over Muslims in America. Posted: 12/31/2010 11:20 am EST. http://www.huffingtonpost.com/qasimrashid/the-war-over-muslims-ina_b_801427.html

7 Muslim Publics Share Concerns about Extremist Groups. http://www.pewglobal.org/2013/09/10/muslimpublics-share-concerns-about-extremistgroups/
While Islamic Militant, for example AlQaeda, is labeled as either radical or extremist, Muslims who reject and oppose the ideology of the radical group are considered as the moderates ${ }^{8}$. These moderates find Islamophobia, one of them, a result of religious extremism done by certain radical group of Muslims. Imam Feisal Abdul Rauf, the founder of Islamic Centre in Ground Zero New York, is one speaking for the religious moderation. His thoughts are presented in many writings and speeches. One of his works is a book entitled Moving the Mountain: beyond Ground Zero to a New Vision of Islam in America. Within the book Imam Rauf elaborates Islam and some related issues that become questions of especially the public of America. His thoughts, as presented on Moving the Mountain, explain Islam and at the same time clarify bad images of the religion which are the basis of Islamophobia. In the issue of culture, for example, Imam Rauf has a unique thought. While some people are cynical in meeting up Islam and America, Imam Rauf reconciles the two in an optimistic perspective. According to him, Islam and America are reconcilable. $\mathrm{He}$ suggests that as a spiritual value Islam is adaptable in all cultural situations. For him Islam is already part of America; it is no longer just a foreign import (Rauf, 2012, p. 7).

Related to prejudice against Islam Imam Rauf's Moving the Mountain presents an analytical perspective on it. In response to terrorism and religious fundamentalism,

\section{Moderate Muslim / Moderate Islam.} http://www.commongroundnews.org/term _en_moderate_muslim.php?lan=en 
for example, Imam Rauf stated that "in the past half-century an extremist version of Islam untrue to Muslim history and profoundly dangerous to Muslims and non-Muslims all over the world has tried to hijacked the faith of 1.6 billion people, making it seem parochial, judgmental, narrow, self-righteous, and violent" (Rauf, 2012, p. 3). Rauf argued that a small community of Muslims has made the world see Islam badly. Imam Rauf's ideas promise an optimistic discourse on Islam in America. He ensures people that being a Muslim and at the same time an American is a necessity. While some people are cynically put Islam and America in such contrastive ways, Imam Rauf finds suitability between the two entities (Rauf, 2012, p. 13).

Reading the ideas of Imam Rauf, the writer of the study assumes Moving the Mountain a counter-argument to myths, prejudices, and stereotypes by which Islamophobia emerged. What Imam Rauf has presented through his writings and speeches, in many ways, have also the same spirits with the idea of moderate Islam which is the opponent of radical one. Based on the hypothesis, the writer of the study is willing to analyze Imam Rauf's Moving the Mountain. Indeed, to find whether the ideas are workable and successful in decreasing the phenomena of Islamophobia or not is something difficult to measure. Therefore, the writer of the study will only attempt to know how far Moving the Mountain is in line with the moderate Islam views and see whether it is a counter-argument to myths, prejudice, and stereotypes of Muslims, by which Islamophobia especially in post $9 / 11$ America exists, or not. Based on the background above, this paper aims to discuss in what ways Rauf's Moving Mountain reflects the views of moderate Islam.

\section{Methodology}

In doing the study, it uses library research. The main data is a book entitled Moving the Mountain: Beyond Ground Zero to a New Vision of Islam in America by Imam Feisal Abdul Rauf. Meanwhile, other supporting data are taken from any relevant books, journal, newspaper, and internet sources. The supporting data used here are related to the issue of Islam in America and Imam Rauf. The internet sources will help the writer get the latest information which is concerns about the issue of Islam in America. So does with scientific journals.

The data collected in the study are mostly qualitative ones. However, the writer also collects quantitative data as the supporting arguments. Considering that most of the data are qualitative the writer will use a qualitative method of analysis. The qualitative method of analysis will be concerned with how the available data are interpreted. The qualitative data are usually group of words and sentences. This kind of data cannot be categorized. This is different from quantitative data which comprise statistical and numerical ones.

\section{Discussion \\ Islamic Belief and Moderate Islam}

Rauf mentions that Islam is a religion which the Quran and Sunnah are the basis. The Quran is known to be the holy book of 
Muslims where there collected God's sayings. The Sunnah, on the other side, is the Prophet's customs which is later organized in narratives called Hadith. Rauf affirmed that Islam is not teaching polytheism. Muslims believe in one God that Muslims call Him, Allah, an Arabic term for God. As mentioned by Rauf (2012), "we Muslims acknowledge, affirm, declare, and worship one God. This God, our God, has no partners. The Lord is one. Our single most important act of worship is to declare the following: "There is no god but God." In Arabic: La ilaha illallah" (p. 32).

Within Moving the Mountain, Rauf (2012) discussed at a glance the linkages of Islam with other two big religions; Judaism and Christianity. He stated, "to use metaphor, we have a tendency to think of Judaism as resembling "Moses, Inc.," Christianity as "Jesus, Inc.," and Islam as "Muhammad, Inc." The Quranic truth is that Moses, Jesus, Muhammad, and the countless prophets God sent were regional managers of "God, Inc.," (p. 33). As Rauf has mentioned before, when it comes to the monotheistic concept of theology, Islam does not stand alone. The concept is also found in Judaism. According to Rauf (2012), "if you are Jewish, you may hear the echoes of the Hebrew Shema, "Hear O Israel, the Lord our God, the Lord is One" (in Hebrew, Shema Yisrael, Adonai Elohenu, Adonai Echad, which sounds striningly similar to the first verse of chapter 112 of the Quran: qul huwa-llahu ahad, meaning "Say, He is God: One")" (p. 33). So does in Christianity, regardless the concept of Trinity, Rauf found the spirit of the oneness' of God in this religion. As what Rauf found in a biblical verse, "You shall love the Lord your God with all your heart, and with all your sould, and with all your mind". According to Rauf (2012), within the belief of Christianity, "this is the greatest and first commandment" (p. 34). Beyond that, Islamic teachings also require Muslims to believe in Taurat, which is Jewish's holy book, and Bible, which is Christians' holy book. In addition, Muslims also believe in the Prophecy of Moses and Jesus. These facts become meeting points of Islam and the two religions.

As a religion, Islam has a spirit of moderation in many aspects. This moderation, in turn, leads Muslims to be open minded and to be able to create dialogue with other groups and civilizations. In delivering his views on Islamic Beliefs, Rauf tend to forward meeting points between Islam and other religions, in this case is Judaism and Christianity. In the midst of religious exclusivism practiced by some religious individuals and groups, the moderate Islam encourages the creation of multireligious society which in turn is able to work together in various fields of life. This encouragement at the same time answers the questions of whether Islam could take part in creating a better world civilization or not. Of course, as a part of global community, the Moderate Islam views the cooperation of Muslims with other religious communities in many aspects as a necessity. This also shows the world that, as stated in the Quran, Muslims are an opened religious community. They are open minded with the new traditions but at the same time they do not receive it as it is.

Rauf also has an interesting view on the use of the word Muslim. In accordance 
with him, in the Quran, God has never called the followers of Prophet Muhammad as "Muslims" but rather "believers", which is in Arabic Mu'min (Rauf, 2012, p. 35). This is also what practiced by the Prophet Muhammad where during his life he always call his followers "the believers". A century after the Prophet passed away, the term mu'min changed due to political reasons. This change was made to differ the follower of Islam and other religions, especially Jewish and Christians. Since then, people who follow Islamic teaching are called Muslim not mu'min. In response to this, Rauf (2012) stated

"I almost wish we could use the ancient language and call ourselves "believers" rather than Muslims. In our zeal to exalt our own religions, we lose sight of what we have in common, which is deeper than any particular manifestation of a religious faith. More than once in the Qur'an $(6: 159,30: 32)$ God laments our human predilection to divide ourselves into sects, each delighting and congratulating itself on its limited understanding of "true faith" and looking down its nose as others." (p. 36).

Not only does expect the word "believers" to be used for Islamic community, Rauf also wish the word to refer to followers of other beliefs, especially Jewish and Christians which have the same root with Muslims regarding the Prophecy of Abraham.

Refering to the Quran (3:113-115), Rauf mentioned that among Jewish and Christians, the devoted ones would get God's forgiveness and salvation. Based on this statement, he continued, "so there are upright people of faith of whom God approves, whether they call themselves Christians or Jews or believers or Muslims, and there are hypocrites and evildoers in all these religious catagories as well. The real divide is therefore not between Muslims, Jews, Christians, and Buddhists, but between godly believers and ungodly people, which includes religious hypocrites" (Rauf, 2012, pp. 42-43).

Rauf (2012) argued that, "it is not the religious identity which becomes the differentiator among people, but rather their deeds, whether they are good or bad" (p. 43). Furthermore, the identity as a "Muslim", according to Rauf, should not be something to be proud. This is because "Islam" is the lowest level within Islamic Theology. The more important thing for Muslim is to up grade themselves to the next level that is to be the true believers, mu'min.

The openness of Islam regarding the other religious communities enables Muslims to work together with them in many fields. This is in line with so-called habluminannas, which becomes the Second Commandement in Islam. Rauf has mentioned before, that habluminannas is in other words, to love all God's creatures. The Moderate Islam is known to support the creation of multireligious people by which they can work together as a community of believers. The Prophet Muhammad, as the leader of Islamic communities, has often examplified the importance of keeping good relationship with other religious communities. 
According to Rauf, God's commandments, in this case is forms of worship rituals, are actually meant to make ones aware with the concept loving all God's creatures. Few people have this kind of awareness as many of them usually practice their religion without any contemplation. Whereas, the awareness to love the others is one of important Islamic teachings. Rauf (2012) called this action as "the Second Commandment in Islam". This spirit is also found in Judaism and Christianity (p. 46).

The Islamic history shows the life of Muslims, especially during the leadership of Prophet Muhammad, has been often faced with religious plurality. It shows that Muslims lived in peace with those plural religious communities. In Madina, for example, Prophet Muhammad once initiated a worth political and legal consensus to protect all the religious communities and at the same time to create a cooperation in many fields of life among them.

The moderate Islam sees the extremist groups of religions are one of the sources of religious conflicts. These groups exclusively isolate themselves from other religious communities. They relucatantly get along with other communities. In turn, there emerged fanaticism within these groups. In accordance with Rauf, in order to avoid conflict, religious identity should not be something to be proud in front of other religious communities. The important thing is to spread good deeds.

Based on religious texts and after contextualizing them with the current global era, Rauf views on Islamic belief as found in the first chapter of Moving the Mountain is relevant with the Moderate
Islam spirit. To reaffirm, these relevances cover; the spirit of seeking for meeting points among different religious communities and the encouragement in creating a just multireligious community. These two points becomes the suitability of Rauf's View with Moderate Islam.

\section{Sharia and Moderate Islam}

Having understood Rauf's View on Sharia, the writer has found there are at least two relevances of this discussion with Moderate Islam views. The first one lies on the point where Sharia should not be negatively stigmatized, especially by nonMuslims. The second is Rauf's inclusive interpretation on Sharia, by which he meets up Sharia and other religious and cultural traditions.

Within Islamic teaching there known two scopes of Sharia. The first one is laws in which worship and beliefs matters are regulated. The second one relates to the worldly matters (mu'amalat). These two coverages are very essential in the Islamic practice of Muslims. However, laws stated in the Quran and Hadith are not catagorically practiced. There is a mechanism to do, in which Islamic scholars call fiqh al-shariah, before it becomes Islamic legal products and systems. Further, the purpose of Shariah, as formulated by Islamic scholars, lies in so-called maqashid al-shariah, which literally means "the objective of Shariah". This concept is manifested into six rights. The six ones are rights to life, religion, mind, property, family, and dignity. Sharia is basically different from what some people think; it is cruel and inhuman. In fact, Sharia is meant to glorify human. As written by Rauf, "helping people satisfy 
those needs is a good deed, a positive good. Islamic law goes even further: it requires us to help other human beings eat, find shelter, worship, get educated, live in a dignified manner, and get married" (Rauf, 2012, p. 55).

According to Rauf, three big religions; Judaism, Christianity, and Islam, have the same root when it comes to the discussion about God's laws, which is later in the context of Islam called Shariah. Rauf argued that the linkage of the three religions on the matter of God's laws can be seen from the Quran (42:13) where God said, "He has ordained (shara'a) for you as law (din, a word also translated as "religion"), that which $\mathrm{He}$ enjoined upon Noah, and that which We revealed to you, and which We enjoined upon Abraham, Moses, and Jesus" (Rauf, 2012, p. 49-50). The three big religions mentioned before basically each of them continues the God's laws brought by the previous prophets and it is the following prophets who complete the previous ones. In accordance with Rauf, in the era of Muhammad's leadership in Madina the penal law used is taken from Bible, before it is then changed with the Quran. The change from the Bible into the Quran, as Rauf mentioned, is there because of the new contexts (Rauf, 2012, p. 50). So do the other laws brought by the previous prophets. They changed as the new contexts appeared.

Rauf (2012) argued that, "God's laws, as stated in the Quran and Hadith, is Muslims' compass to understand and also to differ between right and wrong behavior: what is ethical or unethical behavior, legitimate or illegitimate governance, appropiate civil and criminal punishments, and protection of human rights" (p. 50). Further, Shariah is terminologically from the word shar' which means "rules". The term evolve to and popularly known as Shariah.

Nowadays, the term Shariah is often narrowly understood. It is even distorted. As Rauf stated, "Sharia, or Sharia law, as English speakers commonly call it, conjures up images in American minds of the Taliban stoning adulterers in stadiums or of the Iranian moral police arresting women for inapropiate dress" (Rauf, 2012, p. 50). In the context of America, when one asks for the definition of Sharia, he firstly should imagine the US' Constitution, Declaration of Independence, which is the American fundamental laws, in order to make it easier to understand. Of course, the US Constitution is different from Sharia. While Sharia relates to religious values, the constitution fully reflects secularism. By firstly understanding the Constitution people would at least get a description on how Sharia looks like and served.

Taken from the Quran and Hadith, the Islamic laws in fact absorb the legal classifications of pre-Islamic context where there found: criminal law, the law of personal status, the law of contracts, laws of governance, and laws of nations (Rauf, 2012, p. 55). Further, Rauf stated, "shariah constitutes a very large and highly developed body of rulings and interpretations stretching back fourteen centuries that has given rise to a number of different schools of interpretation" (Rauf, 2012, pp. 55-56). Shariah is also in fact a term whose practices are varied. It is not apart from the contexts and interpretations. 
Becoming one of what most American fear is that Sharia is a physically brutal and cruel punishment considered applicable for the seventh century of Islamic society only. Most people, in fact, do not realize that American Muslims have practiced Shariah in America all the time. The Islamic practices; five time prayers, fasting during ramadhan, to only eat halal food, and other form of worships are the manifestation of Shariah (Rauf, 2012, p. 62).

Suspicions on Shariah as a brutal and cruel punishment are there due to some reasons. The practice of death penalty, in this case is rajam, in several Muslims' countries become a fear for non-Muslims. Without first understanding the context and history, indeed, this form of punishment would seem to be brutal. As a result, Islam is again suspected to promote violence and inhuman. On this matter Rauf (2012) argued,

"the biblical punishment for adultery was stoning, but there are few op-ed articles in mainstream newspapers accusing Jews of legalized brutality. English common law provided for unmaginably cruel and painful public punishment, tearing flesh off criminals with red-hot metal tools, for example, for minor property crimes as recently as the eighteenth century, but no respectable legal scholar argues that we need a new foundation for American criminal law since it is based on that of our brutal English forebears. Singapore's practice of caning originated in that country's British colonial past, not its multireligious present. Ling Chi, the Chinese punishment known as "death by thousand cuts" or "slow slicing," survive in that legally Confusician country until the early twentieth century." (p. 62).

Rauf's statements above shows that the practice of death penalty, in this case is rajam is not the only one seemed to be a brutal and inhuman punishment. In Muslim majority countries such as Indonesia, Turkey, Malaysia, and most of African Muslim majority countries there not even practiced rajam in national constitution. This does not mean there is no any kind of adultery. Yet, the countries use positive laws instead.

Moderate Islam views the acts of terrorism and violence done by some radical Islam groups are motivated, one of them, by the desire to formalize Sharia within a state. Of course, to be underlined, Sharia they meant is based on their interpretation. Some of radical Islamic groups such as IS and Al-Qaeda are, as explained in the previous chapter, representations of the groups struggling for this formalization of Sharia. In practice, these groups would often use violence in attaining their goals. Many acts against the law, say, assault to the legitimate state, suicide bombs, and other violent attacks are done by some of these groups. Apart from a political and an economic tendency, a religious motive that is the motivation of the establishment of Islamic State, would encourge these groups.

As explained before, the radical Islamic groups see Sharia, in which they textually interpret, must be totally implemented by Muslims. This total implementation would only realize under the establishment of an Islamic State or some call this Khilafa. This kind of State is considered able to guarantee and to keep the implementation 
of Sharia. In practice, many of the radical Islamic groups use a jargon jihad to do their actions. Many Muslims, due to their ignorance, are interested in such kind of jargons. Lured by God's promises, it is said that those who conduct jihad would enter the paradise, some people are trapped in such kind of Jihad. Soon, heard many victims of suicide bombs and other violences.

The radical Islamic movements are indeed not all using such kind of violent and terrorism acts. Hizbut Tahrir is one of some other non-violence movements struggling for the formalization of Sharia. In practice, this organization against democracy, which they think do not give space for the implementation of Sharia. Of course, there are many different interpretation of Sharia between the radical and moderat Islam groups.

Jihad, which some people identify it a radical Islamic terms, in fact has a large scope. It is not merely a physical struggle, say war. Before deciding to use a physical jihad, Muslims should fulfill many strict conditions. Seeing the phenomena of Jihad done by some radical Islamic groups the writer found it incompatible with moderate Islam views.

The violent and terrorism actions done on behalf of Islamic Jihad are in turn lead to the fear of Islam. As a result, many people, especially non-Muslims would find Sharia a frightening law to implement. In today's phenomena, the radical Islamic groups even publicly show their inhuman actions, such as as done by IS; decapitation on behalf of Islam. Instead of promoting a peaceful Islam, this group, in the name of the implementation of Sharia, make the images of Islam even worse.

Different from radical Islamic groups, Rauf understand Sharia in scientific point of views. Of course, Quran and other religious texts are used to make the interpretations. Besides, he also uses other Islamic scholars' point of views as the basis of his views. Within his analysis, there are at least some essential points of Sharia. The first, Sharia is God's laws which is intended as a means of human's beneficence. The second, that the concept of Sharia is also found in two big religions' traditions; Judaism and Christianity. The third, Sharia is contextual and adaptable with different situations. The fourth, Sharia is not a brutal and cruel laws. The fifth, there is no need to formalize Sharia.

The first point, that Sharia is there to the beneficence of humanity. This principle is in line with the spirit of Moderate Islam. In this case, to creat beneficence people need legitimate efforts or things do not violate the enforced laws. Thus, moderate Islam views on violent Jihad, on behalf of the enforcement of Sharia, does not reflect the substance of Sharia. As far as the Muslims' rights, for especially being able to practice worships and other rights stated within maqashid al-sharia, are guaranteed, there should be no any requirement, even with violence, to the legitimate state. As Sharia is meant to keep the existence of human, any violence which later could kill human's life is not a justified way to attain maqashid al-sharia.

The second point, that Sharia is a continuity of God's laws delivered to the previous prophets, before the coming of Muhammad SAW. This one reflects the 
moderate Islam view in term of religious tolerance. Despite of the fine lines of difference within three religions; Judaism, Christianity, and Islam, these three religions in some ways practice the same values. Rauf himself meets up those three religions, in the discussion of Sharia, optimistically. This effort, according to Rauf, would decrease the potential of religious conflicts. Rauf wants to build a harmonious dialogue among the three religions, as they have many followers.

The third point, that Sharia is contextual. This one consequently reflects the flexibility of Sharia where especially Muslims would be able to practice Sharia at any era and condition. Sharia would also be able to cover non-Muslims due to its universality. As maqashid al-sharia would not only deal with Muslims, but it also every human's rights, Sharia is supposed to be applicable in every place and time. In this point, Rauf's View on Sharia are in line with moderate Islam. Within the interpretation lies a flexibility in "modifying" Shariah, in the context of muamalat (social relation), as far as it doesn't against the core values of Islam.

The fourth point, that Sharia is not a brutal and cruel punishment. Seeing the implementation of Sharia in some conservative Muslim majority countries, some people negatively consider the God's laws are inhuman and thus incompatible with the modern era. The practice of beheading and stonning punishment in Saudi and Pakistan, for example, it then often becomes ones' reason to fear socalled Sharia. In their opinion, such kind of punishment would be not compatible with countries where human rights are upheld. Rauf himself argued that that opinion is not right. Sharia, according to Rauf, has been long practiced especially by Muslims in America. Within Sharia such kind of physical punishments are meant to torture ones' life. It is yet to honor human's dignity. Beyond that, forgiveness is worth doing than conducting physical punishment. This point is in line with moderate Islam's characteristic in which dialogue and peaceful ways in solving problems and legal disputes are its spirit. At the same time, within this point Rauf has also clarified misunderstandings on Sharia.

The fifth point, that there is no need to formalize Sharia. This point is in accordance with Moderate Islam views in term of the relation between religion and state. As discussed before, moderate Islam sees the state as the protector of the existing religions. Whatever its forms, the essence of a state is to guarantee the freedom of religion which is also stated in maqashid al-sharia. In this context, the state should not interfere ones' religiosity. The state is served to facilitate and guarantee people's religios freedom and safety. A state with such kind of criteria would have reflected the spirit of Sharia. Thus, this becomes the meeting point of this view with moderate Islam.

Rauf encourages the implementation of Islamic values within the American context. He himself argued, "we need to express Muslim theology and jurisprudence within American jurisprudence and law, American culture, American politics, American Architecture, and even American musical forms. In that sense we can speak of an authentic American expression of Islam" (Rauf, 2012, p. 80). In accordance with Rauf, in 
today's phenomena there a lot found misunderstandings in the implementation of Sharia. As what he said, "too many Muslims today are commiting the same sins that our predecessors committed by equatting the letter of the law to God. Law, or Sharia, is made for us, and not for Sharia" (2012, p. 80). In this case, Rauf expects Muslims to study and understand Sharia in more comprehensive views. In the next page of this part Rauf (2012) stated,

"it is pressing, therefore, that we help our people understand what is eternal in Islam and what is contextual. God Himself states in the Quran that $\mathrm{He}$ sent His messages to different communities through messengers who spoke to the community in their own language; this messengers who spoke to the community in their own language; this certainly means cultures and law too!.” (p. 81).

\section{Religion Tolerance and Moderate Islam}

Moderate Islam sees other religions, especially when it comes to social context, as partners in creating harmony and justice. This can be seen from how Moderate Islam encourages the freedom of religions. The spirit of moderate Islam support the freedom of people in choosing their own beliefs. In turn, religious differences are not the source of conflicts among people. As stated in the Quran, that there is no compulsion in religion, this chapter is in line with moderate Islam views where Rauf appreciate the existing religions, either Abrahamic or nonAbrahamic. While some individuals or groups are busy thinking of inviting people to embrace their beliefs and religions, Rauf promotes the religious tolerance and build cooperation among religious leaders in creating a better civilization.

Quran, as one of the main sources of Islamic teachings, affirmed that God has actually sent many prophets to deliver God's messages before all of the teachings are completed with Quran as the last revelation (Rauf, 2012, p. 88). This, consequently, leads to the facts that there found, out of the differences, the similarities among the God's religions that have been brought by different prophets. These similarities are refering to the core of the religions, teacing the oneness of God and creating harmony in human's life. Due to different contexts and eras, there then emerged difference among the God's religions. Rauf himself stated that,

"just as a garden has many different flowers, not simply one variety or color, the most important work confronting all humanity, whatever our faiths, is to find the platform on which we can unite in spite of our differences, understanding that those differences are insignificant compared to our similarities, and whatever our differences, we have an obligation to protect every other community. That is what characterizes America its best, and we Muslims have our own responsibility to help create unum out of this pluribus." (p. 89)

According to Rauf, people should act and think wisely in response to the religious differences. As the substance of the religions are the same, the differences are rather beauty, symbolized by flowers, than destroyer of people's harmony. In the context of America, moreover, there have 
been commonly known that plurality in many terms are the core of this society. Regarding those who have fanatical views on their identity Rauf (2012) affirmed,

"is God as interested in the distinctions between Sunni and Shia, Catholic and Protestant, Reform and Conservative, and other human made religious distinctions, as we are? The Quran (23:52-53) quotes God telling His messengers, including Moses as and Jesus, "Surely this your community (of believers) is one community, and I am your Lord; so keep your duty to Me. But they became divided into sects, with each group reveling in what differentiates them." (p. 93).

As noticed by the history, Muslims have long interacted with varied groups, in term of cultures, religious views, and other backgrounds. Within the leadership of Prophet Muhammad in Madina, for example, the religious differences among the community is not a source of conflict. Religious plurality is a reality to face with which people work together especially in the social, economic, political, and other contexts. Those have concern on how creating moderate Muslims are aware with the facts, so they do not easily and blindly marginalize other religious individuals and groups.

Rauf seeks for meeting points especially among three Abrahamic religions. In addition, in seeing the relation of Islam with other religions Rauf also did the same things. Instead of being exclusive on the matter of religious identity Rauf, with other religious leaders, promots interfaith dialogues. This is done in order to counter the assumption that Islam is a closed and anti-dialogue religion.

As stated in the Quran, there found a term, "people of the book" with which God refer to the adherents of Judaism and Christianity. On this matter Rauf (2012) stated,

"we Muslims should feel enormous kinship with Jews and Christians, partly because we are kin, literal siblings in the great monotheistic adventure that began in the ancient Near East several thousand years ago. But also, in our holy book, the Quran, God speaks frequently the "people of the book", Jews and Christians, whom we are taught to consider our brothers and sisters." (p. 95)

Despite of many differences among these three religions, for example in the concept of theology, especially Muslims, according to Rauf, should be more aware with the meeting points of the three religions.

The main point of moderate Islam in positioning other religions is to avoid exclusivism and to encourage tolerance and cooperation in many fields of life among the religious communities. In the current global era, not only do varied ethnics, religious communities' cooperation is also urgently needed in creating a better civilization. As plurality is a neccesity, ones are supposed to be able to live in such plural communities.

Not only does Rauf appreciate Abrahamic religions, to those non-Abrahamic ones this Imam has also given wise and moderate views. Rauf argued that all people, as God mentioned in the Quran, have their own prophets. These prophets 
deliver the messages from the same God. Further, he stated, "Muslims believe, as the Quran (10:47) says, the God "raised in every nation a messenger, "or representative, of God to speak to the people in "their own language." However, some (of the messengers) we have named, and some We have not named" (Quran 4:46)" (Rauf, 2012, p. 97). According to Rauf, ones should not easily reject the existence of non-Abrahamic religions. They are not only matters of human rights, but also there should be known the relevance of the religions with Islamic teachings so that there are understandings. Rauf (2012) continued,

"so even though the Quran does not explicitly refer to Hindu, Buddhist, Confucian, Jain, Shinto, Zoroastrian, or Taoist religious practice, we must acknowledge that all of these adherents had to have prophets who taught the to practice in this way, and we Muslims are obliged to honor the practitioners of these faiths." ( $p$. 98)

Rauf encourages Muslims, to not marginalize other religions especially those non-Abrahamic ones. Otherwise, Rauf offers wise views on the matter, saying that there are probably meeting points between the Abrahamic ones with non-Abrahamic ones. He streeses the need of promoting tolerance among the adherents.

\section{Modern American Woman and Moderate Islam}

Rauf's ideas with regard to women have some relevancies to the spirit of moderate Islamic views. These relevancies are located at points which confirm that women have an equal status with men and some restraints on women that have been legitimized by religious arguments should be re-examined.

The existing myths on the views of Islam to woman is negative. This sex is often seen as the oppressed ones within Islamic society. Prophet Muhammad would become one who is badly stereotyped regarding his attitude toward women by some people. In this case, the issue of polygamy is often seen as a justification of the stereotype where Muhammad is women oppresor. Out of the people's ignorance on the truth, borrowing Rauf's statement, Prophet Muhammad is a true feminist. As Rauf stated, "the Prophet Muhammad brought enormous changes for women and to their status, explicitly, and implicitly, so much so that I consider him an early women's liberationist, remarkable for his time" (Rauf, 2012, p. 107).

Prophet Muhammad himself, out of the existing prejudices, has in fact done many revolutions in relation with women's position. On this matter, Rauf (2012) stated,

"at the time of the Prophet, women were the legal property of men in the Arabian Peninsula, but also throughout the rest of the Middle East and in Europe, China, and Africa. Generally men could marry as many women as they wished, and women had virtually no property or inheritance rights. The Prophet determined that women could no longer be disinherited (neither could men)." (p. 107). 
Many of the haters deny the contexts of Prophet Muhammad's life. This, in turn, often results in misunderstanding and misinformation on the actions and policies done by the Prophet regarding the women status and position. On polygamy, for example, there is a few people know that a permission to marry four women and treat them justly in Islam is a revolutionary where before the coming of Islam women are treated as men's property with whom they can marry as much as possible. Moreover, this polygamy is not a encouragement but a permission done under strict conditions.

In living his life as the messenger of God Prophet Muhammad took Khadija as his wife. It is important to know that the Prophet married Khadija monogamously for twenty five years. It is not like what some people said, Prophet Muhammad treated Khadija humanly. In many occasions the Prophet also involve Khadija in his religious matters. When the Prophet first received God's revelation, it was Khadija to first listen to the Prophet's story. This showed how Muhammad and Khadija relate as ideal husband and wife.

The equality of women with men is not solely the result of a person's thought. As it is known, this spirit has a religious foundation in the teachings of Islam. Moderate Islam, as an idea, is then just trying to remind people who are denying the fact that women and men have the same position in the eyes of God. Departing from this idea, there should be a wider awareness in which people will consider women to be no longer regarded as second-class human beings. Especially in today's global era, where women, together with men can support each other and become a partner to build a better civilization.

The need to encourage the opportunity for women to be able to play a role in public spaces, as stated by Rauf, further reflects the spirit of moderate Islam. With more concrete participation in public spaces, Muslim women will no longer be seen as second-class human beings as alleged by some people.

Equal opportunity to play an active role in various aspects of life, in the view of moderate Islam, should not then deny the role of men. In this case the moderate Islam believes that it always requires cooperation between the two parties, men and women. Not vice versa, each is dominating one another. Here is a reflection of the moderation of Islam where a person is not allowed to be stuck in one particular thought. Such as a particular thought that promotes female role so freely (without limitation) and the other thought that give a lot of limitations for women.

Within Islamic history, there found records on the involvement of women in many crucial events of Muslims' early life. This, one of them, can be seen from war. As stated by Rauf, "in the battles on behalf the believing community, women accompanied male warriors, to fight, to encourage and prod their warriors, and to nurse the wounded. These battles could not have been won without the vital support of women" (Rauf, 2012, p. 110). These facts have at least generally explained to people that the participation of women in the public sphere is a necessity in Islamic teaching. 
Nevertheless, it is still found some Muslim majority countries treating their women citizen conservatively, such as prohibiting them to participate in the public domains. On this matter Rauf said, "it is undeniable that in many Muslim countries around the world, women's rights and oppotunities are far more restricted that in Western countries. In fact, according to the World Economic Forum, twenty of the twentyfive "worst" countries in the world for women's participation in society have Muslim majorities" (Rauf, 2012, p. 111). Out of the reality, American Muslim women at the same time hold a higher level of education from American in general. They are even more educated than the Western women. Rauf (2012) argued,

"I think we need to pause and consider the achievements of Muslim women in our country (America). They have fully grasped the opportunities available to them. They have not walked behind their men, remaining subject to ancient patriarchal systems widespread in the developing world. They are attending college, improving their employment opportunities, attending mosques, and being civically engaged, all the while remaining proud Muslims in the face of a popular culture that is often condescending at best and hostile and violent at worst." (p. 111).

Rauf supports especially Muslims to protect of women's human rights. In today's era this effort is not only in line with what Prophet Muhammad exemplified, but it is also today's life demand where women as well as men are the subjects of just and advanced world development. This is affirmed by Rauf, "given the Prophet's revolutionary intervention in the structure of gender relations, Muslims today need to maintain the Prophet's groundbreaking desire to continually improve the status of women" (2012, pp. 111-112).

Historically, in the beginning of the birth of Islam, many Muslims have involved women in the fight for the existence and rights of Muslims, including in the political field. As previously stated by Rauf, many of the Muslim women participate in fighting to defend the rights of Muslims at the time. It can be seen as basic one that affirms the equality of women and men in Islam and at the same time shows the division of roles between men and women.

Rauf puts much attention on the advancement of especially American and worldwide Muslim women. He himself uttered, "my hope for American Muslim women is that they will step further into the limelight, transforming the images non-Muslims have of Muslim women around the world" (Rauf, 2012, p. 113). Bad images of Islam in the matter of women then should be erased. This, one of them, can be disappeared through the availability of supports from especially Muslims leaders in America. As stated by Rauf, "those of us who hold religious authority have an obligation to educate our corereligionists about women's place both in Islam and in American society" (Rauf, 2012, p. 114). Despite of the optimism, there still found many stereotypes and myths of Muslim women in American life. Thus, according to Rauf, there should be efforts in countering such misunderstandings. 
Rauf's appreciation to the progress of Muslim women in many Muslim-majority countries also implies a greater desire to promote Muslim women, especially in America. According to Rauf himself, American Muslims is expected to be a role model for Muslim women in the world. Unlike the indications of conservatism that emerged in Muslim countries, such as Saudi Arabia and Pakistan, for example, America as a democratic state is considered to be able to provide abundant opportunity for women to take part in public spaces.

In addition to the empowerment of women, the moderate Islam also calls for scientific studies, of course, primarily on the foundation of Islamic texts, in order to revisit the assumptions that have tended to put women as second-class human beings. Rauf also criticized the symptoms of conservatism that is practiced by some radical groups, such as the Taliban. In treating this group of women, or the like, tend to be oppressive. For Rauf, such indications, which are said by these groups have religious legitimacy, should be reviewed. This is because at some point someone will notice that the placement of women as second-class human beings is actually a result of the patriarchal system in which is misused by some people.

Rauf's ideas are relevant to the moderate Islamic thought in terms of the empowerment of women and scientific assessment of the actual role of women in Islam. In contrast to the views of radicals in which put the position of women to be placed in domestic spaces. Moderate Muslims are encouraging women to play an active role in various aspects of life. Of course, this has to be done responsibly and by keeping the mutual cooperation with men.

\section{Conclusion}

American Muslim is one of religious minorities group in America. Although they are considered as minority, for some of the last century, American Muslims have been living side by side with the majority. Nevertheless, being apart from their successful participation and integration into some of the American life, American Muslims have also encountered and become the object of the suspicion, prejudice, discrimination by majority of American society. The long production of bad images and myths about Islam as the religion and Muslims become one of the causes to rationalize their treatments for Muslims.

Among the bad image that is often pinned on Muslims is that Islam supports terrorism and violence so that all Muslims are terrorists and harsh. Images of this kind appear not without cause, the tragedy of war, especially in the Middle East and Islamic extremism practiced by a minority of Islamic groups make most of American society oversimplify it with Muslims widely. This is compounded by some media that also proclaim Muslims unfairly and overly generalize.

The tragedy of $9 / 11$ that claimed the lives of thousands of people, in turn, is considered to be the beginning of the entrance for rooted suspicions and hatreds against American Muslims. The tragedy was treated as if it was justifications for the incorrect prejudice that portray Muslims are no different with terrorists. The involvement of Islamic militant groups in the deadly attacks has extended 
the wrong prejudices against American Muslims. As the worst point, the tragedy of $9 / 11$ has triggered what is now called as Islamophobia. At this point, the resentments that arise are no longer based on understandable reasons and sensible. Muslims are suspected, feared and hated blindly.

Based on a review of the existing data, the writer found the tragedy of $9 / 11$ as a pivotal moment in the dynamics of the life of American Muslims. The tragedy provides a significant change with respect to the position of Muslims in America. Two of the changes that the writer have found, first is the escalation of prejudice and hatred against Muslims and second, the growing population of Muslims is even more rapid. The increasing prejudice and hatred against Muslims is certainly not without reason, by recollection of the tragedy of 9/11 as one among many human tragedy that claimed many lives, it is normal if the hatred are given to the perpetrators and those that are identical to them. At the same time, amid a wave of suspicion and hatred against the Muslim, some of American society becomes curious about Islam, which is considered a terrorist religion. This curiosity about the religion used as a shield by the perpetrators of $9 / 11$ is further strengthened and encouraged some Americans to study Islam deeper. Starting from the curiosity of the truth of whether Islam teaches terrorism or not, many of the American people fell in love with Islam. Most of these people realize that Islam is far from what had been alleged. Apparently, Islam is not a monolithic thing, and the realization that some of the Islamic groups have been misusing religion for vested interests.
In the result of the findings, this thesis concludes that the thought of Rauf on Moderate Islam revealed in his book comprising of, on Islamic Belief, Islam is a monotheistic religion brought by Prophet Muhammad. The essence of this teaching is monotheism, which further obligate its follower to be a spreader of peace. Despite the fact that Islam is divided into many groups which also lead them to have different opinions in the practices of worship, the basic foundation to belief in one God and the Prophet Muhammad as the last prophet often become a meeting point. At the same time, the moderate Islam requires Muslims to be the people who love peace and obey the commandments of the Lord. Moderate Islam is a reflection of the teachings that emphasize obedience to God and at the same time able to contribute positively in the lives of fellow human beings. These points make the idea of part one is relevant to moderate Islam.

Later on, on Shariah in America, the main idea in this discussion is whether the implementation of Shariah is relevant to American life. Imam Rauf explains that the Shariah is the law of God which is becoming the main foundation of the revelation for each Prophet. Because of the context and circumstances are varied, the Shariah brought by the Prophets might be different also in its practice. Even though it is different, Shariah essentially has the same goal. These objectives are formulated in Maqashid Al-Shariah which include; the guarantee of the right to life, the right to think, the right to marry and have a family, freedom of religion, and the right to dignity. It is unlike the misperception and the allegation for the 
Shariah, Shariah is not merely a cruel physical punishment. Shariah, to a certain extent, is in line with the guarantee of human rights as stated on political consensus in this modern era.

With such a broad definition of Shariah, Imam Rauf considers that in many ways Muslims can practice Shariah. Not only because the right to religious freedom is guaranteed here, but also because the life of American society is in line with the spirit of Islam. This notion of common ground with moderate Islamic thought lies in the easiness offered by moderate Islam to the Muslims where Muslims become a minority. In America, where Islam is the religion of a minority, Muslims often wonder if its presence in these places can be justified by religion. Given the idea that the obedience to Shariah is one measure whether someone is considered as a Muslim or not in the eyes of God, then such question naturally arises. Shariah, which was narrowly defined as a cruel physical punishment, actually it has a broad meaning and Imam Rauf believes that the Shariah is applicable anywhere because it can be adjusted and practiced according to certain context. This idea makes it consistent with the moderate Islam where a settlement between context and religion is a necessity, as long as it does not violate the principles of religion.

On Islam and Other Religions, Islam is a religion which emphasizes tolerance towards other religions. Even further, in this part, it is explained that Islam has a close relationship with the two major religious traditions, namely Jews and Christians. However, it does not mean that Islam only emphasizes tolerance of the two religions. Basically, as the Lord himself who guarantees freedom of religion through his teachings, Islam respects the existing plurality. Such practices in which the spirit of tolerance have been demonstrated by the Prophet Muhammad as the leader of the Muslims and the Sahabi and the Salih people. In line with this, the moderate Islamic group views the other religions as a partner in building a civilization. By doing so, the shared respect to protect each other's faith must be maintained in order to create a secure life and just civilization, as represented by the Prophet Muhammad, in the era of the leadership of the Prophet in Medina, religious groups at that time were able to coexist with one another.

Meanwhile, on the modern American Woman, women in Islam have equal status with men. Therefore, women also have the same opportunities as men in public spaces. The restraint against women that occurs in some Muslim-majority region is rooted in conservative interpretations and does not see the current context. Moderate Islam considers that women in modern times should be able to do the same things as men perform in public spaces in order to build a better civilization. Many religious texts affirm the equality of women with men in Islam. Without giving a lower profile the role of men, women in Islam have also significant role in creating a better life.

\section{References}

5 Myths About American Muslims 10 Years After 9/11. Posted: 09/08/2011 6:33 pm EDT. Retrieved from http://www.huffingtonpost.com/eng $\mathrm{y}$-abdelkader/myths-about- 
american-muslims-after-

911_b_946003.html

Defining "Islamophobia." Retrieved from http://crg.berkeley.edu/content/islam ophobia/defining-islamophobia

Eck, Diana L. A New Religious America. USA: Harper Collins E-Book. 2001

Islamophobia: Understanding AntiMuslim Sentiment in the West. Retrieved from http://www.gallup.com/poll/157082/ islamophobia-understanding-antimuslim-sentiment-west.aspx

Islamophobia and Criticism of Islam. Retrieved from http://www.theaugeanstables.com/re flections-from-seconddraft/islamophobia-and-criticism-ofislam/

Khan, M. and Ecklund, K. (2012). Attitude Toward Muslims American Post 9/11. Journal of Muslim Mental Health (2012). Mental Health Online. Retrieved on April $25^{\text {th }}$, 2014 from http://hdl.handle.net/2027/spo.1038 1607.0007.101

Muslim Publics Share Concerns about Extremist Groups. Retrieved from http://www.pewglobal.org/2013/09/ 10/muslim-publics-share-concernsabout-extremist-groups/

Moderate Muslim/Moderate Islam. Retrieved from http://www.commongroundnews.org /term_en_moderate_muslim.php? lan=en

Peek, L. (2011). Behind the Backlash: Muslim Americans after 9/11. Philadelphia: Temple University.

Pew Global Research. (2014). Concerns About Islamic Extremism on the Rise in Middle East. Retrieved from http://www.pewglobal.org/2014/07/ $01 /$ concerns-about-islamicextremism-on-the-rise-in-middleeast/

Rauf, A. F. (2012). Moving the Mountain: Beyond Ground Zero to a New Vision of Islam in America. New York: Free Press.

The War over Muslims in America. Posted: 12/31/2010 11:20 am EST. Retrieved from http://www.huffingtonpost.com/qasi $\mathrm{m}$-rashid/the-war-over-muslims-ina_b_801427.html 